\title{
Upaya Pencegahan Radikalisasi Dini Pada Siswa Melalui Program Unggulan di SDNU Metro Barat Tahun Akademik 2019/2020 (Aspek Ideologi Beragama Dan Sosial)
}

\author{
Masrurotul Mahmudah $^{1}$, Muh. Ngali Zainal Makmun ${ }^{2}$ \\ Institut Agama Islam Ma'arif NU Metro Lampung \\ 1 mahmudahmasrurotul1@gmail.com, \\ zainalalmakmun5@gmail.com
}

\begin{abstract}
In the current stage of development has an impact on the development of human thought patterns on the attitude of individual religiosity. So there is an abuse of religious principles and has been widely applied to children with the lure of jihad fi sabilillah and fighting in the way of Allah guaranteed heaven. Therefore in this study raised a problem, namely: Why should there be efforts to prevent early radicalization in students through excellent programs at SDNU Metro Barat Academic Year 2019/2020 (aspects of religious and social ideology) ?. The research is descriptive analysis with two approaches namely ideological and social. In extracting data by interview, observation and documentation. While the validity of the data uses data triangulation. From data collection and data analysis, it can be seen that the importance of efforts to prevent early radicalization in SD NU Metro Barat has a superior program is to strengthen religious ideology understanding in children / students, so as to minimize the occurrence of doctrination related to radicalism under the guise of reward and heaven
\end{abstract}

Keyword : Early Deradicalization, Religious and Social Ideological Approaches

Abstrak : Dalam kancah perkembangan zaman ini berdampak pada perkembangan pola pikir manusia terhadap sikap religiusitas individu. Sehingga ada yang penyalahgunaan prinsip beragama dan sudah banyak diterapkan pada anak-anak dengan iming-iming jïhad fi sabilillah dan berjuang dijalan Allah dijamin surga. Oleh karena itu dalam penelitian ini mengangkat sebuah masalah yaitu: Mengapa harus ada upaya pencegahan radikalisasi dini Pada siswa melalui program unggulan di SDNU Metro Barat Tahun Akademik 2019/2020 (aspek ideologi beragama dan sosial)?. Adapun penelitian ini bersifat deskriptif analisis dengan dua pendekatan yaitu ideologis dan sosial. Dalam penggalian data dengan wawancara, observasi dan dokumentasi. Sedangkan keabsahan data menggunakan Trianggulasi data. Dari pengumpulan data dan analisis data maka dapat diketahui bahwa pentingya upaya pencegahan radikalisasi dini di SD NU Metro Barat mempunyai program unggulan adalah memperkuat pemahaman ideologi beragama pada anak/siswa, sehingga

AR-RIAYAH : Jurnal Pendidikan Dasar Vol. 4, no. 1, 2020

IAIN Curup - Bengkulu 1 p ISSN 2580-362X; e ISSN 2580-3611 http://journal.iaincurup.ac.id/index.php/JPD 
meminimalisir terjadinya doktrinisasi terkait radikalisme yang berkedok pahala dan surga.

Kata Kunci: Deradikalisasi Dini, Pendekatan Ideologi Beragama dan Sosial

\section{PENDAHULUAN}

Islam adalah agama Allah SWT yang diturunkan kepada seluruh umat manusia melalui Nabi Muhammad SAW, demi tercapainya keharmonisan dalam sebuah hubungan yaitu hubungan antara manusia dengan Tuhannya juga hubungan manusia terhadap sesamanya.1 Nabi Muhammad SAW tidak hanya diutus kepada sekelompok umat tertentu saja, melainkan terhadap seluruh umat yang ada di muka bumi. Allah SWT menegaskan hal ini dalam firman-Nya surat Saba' ayat 28 yang artinya: "dan Kami tidak mengutus kamu, melainkan kepada umat manusia seluruhnya sebagai pembawa berita gembira dan sebagai pemberi peringatan, tetapi kebanyakan manusia tiada mengetahui. (Q.S. As-Saba' :28)2

Maksud dari arti ayat di atas sangat tegas dan jelas, bahwasanya di utusnya Nabi Muhammad SAW, tidak hanya untuk umat tertentu, melainkan terhadap seluruh umat meliputi jin dan manusia bahkan seluruh alam semesta. Tuntutan manusia untuk berbuat baik terhadapNya dan terhadap sesama manusia dengan tegas telah diperintahkan oleh Allah Swt. Oleh karena itu, penanaman ideologi sejak dini merupakan hal yang sangat berpengaruh dan sangat berdampak dalam pemahaman beragama seorang anak. Karena pada saat ini anak-anak sudah ikut dilibatkan pada tindakan Radikalisme seperti: adanya bom bunuh diri, diajak ikut demo terkait pembelaan agama, doktrin tentang jihad fi sabilillah, menjadi generasi yang Qur'ani namun hanya tekstual, dan lain sebagainya.

Muculnya gerakan-gerakan radikal, pemahaman yang terlalu ekstrim dalan pemahaman ideologi tertentu atau kelompok tertentu menjadi polemik ideologi, politik, dan akademik sedang menjadi isuisu kekerasan sebagai trending topik dalam berita. Contoh tindakan radikal yang melibatkan anak-anak yaitu kejadian bom bunuh diri di surabaya.3 Dengan contoh lain direalis dari Suara.com. Ribuan

1 A Faiz Yunus, Jurnal Studi Al-Quran, P-ISSN: 0126-1648, E-ISSN: 2239-2614 Universitas Indonesia : 77

2 Al- Qur'an Terjemah Depag RI, Bandung:CV. J-Art 2004, hlm. 431

3 https://www.bbc.com/indonesia/indonesia-44097913, diakses pada 28 Februari 2020 
peserta Aksi Damai Gerakan Nasional Pengawal Fatwa MUI yang dilaksanakan di kawasan Monas, Jakarta Pusat, Jumat (2/12/2016).4

Beberapa kasus yang sudah terjadi maka kita sebagai praktisi pendidikan harus bisa ikut berfikir dan mempunyai upaya untuk meminimalisir radikalisasi yang terjadi pada usia anak-anak. Karena memang itu sangat mempengaruhi pola pikir masa depan generasi bangsa Indonesia. Dengan demikian, penguatan ideologi beragama sejak dini merupakan pondasi utama dalam dunia pendidikan yang berkarakter. Apalagi pendidikan pada jenjang sekolah dasar dimana nilai-nilai keagamaan mulai ditanamkan dan dibiasakan yang di dalamnya memiliki program pengembangan dan penguatan ideologi beragama.

Adapun tempat SD NU Metro Barat dengan alasan bahwa keberadaan SD NU merupakan SD yang baru berdiri dua Tahun dan siswanya sudah 110 siswa sehingga bisa dinilai bahwa banyak masyarakat yang berminat menyekolahkan anak-anaknya disekolah tersebut, selain itu SD NU sifatnya bernuansa umum karena dibawah naungan Pendidikan Nasional (DIKNAS) namun mempunyai program-program keagamaan yang bagus. Melihat dari profil sekolah yang masih baru namun peminatnya sudah banyak itu menunjukkan ada keistimewaan pada sekolah tersebut. Selain itu para siswa siswinya pun lebih Heterogen dalam hal baground pendidikan ideologi keluarga. Sehingga menurut peneliti lebih menarik untuk di kaji secara mendalam tentang peran guru dalam menguatkan ideologi beragama sebagai wujud upaya pencegahan radikalisasi dini pada siswa melalui program unggulan di SDNU Metro Barat Tahun Akademik 2019/2020 ( penilaian aspek ideologi beragama dan sosial).

Mengapa harus ada upaya pencegahan radikalisasi dini pada siswa melalui program unggulan di SDNU Metro Barat Tahun Akademik 2019/2020 (aspek ideologi beragama dan sosial)? Untuk mengetahui upaya pencegahan radikalisasi dini pada siswa melalui program unggulan di SDNU Metro Barat Tahun Akademik 2019/2020 (aspek ideologi beragama dan sosial) dari segi praktik ideologi beragama maupun prilaku sosial.

\section{LANDASAN TEORI}

\section{Radikalisasi Dini}

4 https://www.suara.com/news/2016/12/02/084807/aksi-bela-islamjilid-iii-demonstran-nekat-bawa-anak-kecil, diakses 28 Februari 2020 
Menurut terminologi yang dikutip oleh Syamsul Ma'arif Syamsul Ma'arif, radikalisme adalah paham atau aliran yang sering berpandangan kolot, bertindak dengan kekerasan dan bersifat ekstrem untuk merealisasikan citacitanya. 5

Radikalisme merupakan bibit lahirnya terorisme. Radikalisme merupakan suatu sikap yang menjungkirbalikkan nilai-nilai yang ada secara drastis lewat kekerasan (violence) dan aksi-aksi yang ekstrem sebagai bukti perubahan secara total dan bersifat revolusioner. Ada beberapa ciri yang bisa dikenali dari sikap dan paham radikal. Pertama: intoleran atau tidak menerima lingkungan sekitar secara utuh (tidak mau menghargai pendapat \& keyakinan orang lain), kedua: fanatik atau parsial (selalu merasa benar sendiri; menganggap orang lain salah), ketiga: eksklusif atau menyendiri (membedakan diri dari umat Islam umumnya) dan keempat: revolusioner membuat perubahan (cenderung menggunakan cara-cara kekerasan untuk mencapai tujuan).

Radikalisme dapat dibedakan menjadi dua bentuk yaitu radikalisme dalam pemikiran dan radikalisme dalam tindakan. Radikalisme dalam pemikiran masih pada level konsep, wacana, gagasan, yang intinya mendukung cara kekerasan dalam mencapai tujuan. Sedangkan radikalisme dalam tindakan berada pada level sosial-politik dan agama.6

Memiliki sikap dan pemahaman radikal saja tidak menjamin seseorang tidak terjerumus dalam paham dan aksi terorisme. Ada beberapa faktor lain yang memotivasi seseorang ikut bergabung dalam jaringan terorisme. Motivasi tersebut memiliki sebab karena beberapa faktor diantaranya yaitu: 1), Faktor domestik, yakni kondisi dalam negeri yang semisal ekonomi, ketidakadilan atau merasa tidak puas dan frustasi terhadap situasi kepemerintahan. 2), faktor internasional, yakni pengaruh lingkungan luar negeri yang memberikan daya dorong tumbuhnya sentiment keagamaan seperti politik luar negeri yg arogan, ketidakadilan global, dan imperialisme modern negara

5 Syamsul Ma'arif, "Ideologi Pesantren Salaf: Deradikalisasi Agama dan Budaya Damai," Ibda' Jurnal Kebudayaan Islam 12 (2014):200, $\begin{array}{lllll}\text { diakses } & 28 & \text { Februari } & \text { 2020, }\end{array}$ http://dx.doi.org/10.24090/ibda.v12i2.2014.pp198209.

6Abdul Munip, "Menangkal Radikalisme Agama di Sekolah," Jurnal Pendidikan Islam 2 (2012), 162, diakses 5 Januari 2017, doi: http://dx.doi.org/ 10.14421/jpi.2012.12.159-181. 
adidaya. 3), faktor kultural yang sangat terkait dengan pemahaman keagamaan yang sangat dangkal dan penafsiran kitab suci secara tekstual yang sempit dan leksikal. Sikap dan pemahaman yang radikal dan dimotivasi oleh berbagai faktor di atas seringkali menjadikan alasan seseorang memilih untuk bergabung dalam jaringan dan aksi terorisme.

Ladang subur tersebut menurut Hendropriyono adalah masyakarat yang dicemari oleh paham fundamentalisme ekstrim atau radikalisme keagamaan.7 Menurut Syaiful Arif bahwa "persoalan yang mendasar ini sebagai wujud adanya kultural Islam di Negara Indonesia. Perwujudan kultural Islam adalah belum tergeraknya modal kultural ini sebagai gerakan. Ia hanya terhenti sebagai cara hidup, yang sering dijalani tanpa kesadaran. Hal ini terjadi karena kultur memang memberikan kenyamanan secara normatif pada level sosial sehinggga tidak memerlukan refleksi pada tingkatan atau level individual. Pada titik inilah perumusan suatu pendidikan kultural Islam penting untuk menggerakkan modal kultural ini agar terwujud dalam sebuah gerakan sosial." 8

Teori tentang radikalisme tersebut diharapkan kita tidak hanya seker memahmi secara arti, namun kita juga harus memahami secara kontekstual, dimana kita semua mampu memperhatikan pola didik anak agar terhindar dari paham radikalisme. Dengan demikian dapat disimpulkan bahwa ada beberapa faktor pendorong munculnya gerakan radikalisme ke dalam 5 faktor yaitu: (a) faktor-faktor sosial-politik ; (b) faktor emosi keagamaan ; (c) faktor kultural ; (d) faktor ideologis antri westernisme ; (e) faktor kebijakan pemerintah

Dari beberapa hal yang dimaksud di atas adalah barubaru ini ada kesengajaan pendidikan yang menggiring pemahaman anak usia sekolah dasar untuk menyetujui dan mengikuti paham radikalisme secara prosedural dan terstruktur, sehingga disebut denga radikalisasi dini.

\section{Pengertian Agama}

Pengertian agama menurut Harun Nasution dalam buku Abudin Nata mengatakan bahwa agama dilihat dari segi bahasa

7 A.M. Hendroprioyono, Terorisme: Fundamentalis Kristen, Yabudi dan Islam (Jakarta: Buku Kompas, 2009), hlm. 13.

8 Syaiful Arif, Deradikalisme Islam (Paradigma dan Strategi Islam Kultural), Perpustakaan Nasional Republik Indonesia: koekoesan, 2010, hlm. 107 
dapat diketahui oleh masyarakat Indonesia yaitu "berasal dari bahasa Sanskrit yang terdiri dari dua susunan kata "a" (tidak) dan "gam" (pergi), sehingga memiliki arti tidak pergi dan tetap menetap di tempat serta di warisi atau diyakini secara turun menurun".9

Selain itu dalam "bahasa Semit berarti undang-undang atau hukum. Sedang bahasa Arab kata ini mengandung arti menguasai, menundukkan, patuh, utang, balasan, dan kebiasaan".10 Adapun maksud dari pengertian tersebut adalah bahwa setiap agama mempunyai kandungan peraturan yang menjadi hukum dan harus disepakati atau dipatuhi oleh para penganutnya. Selanjutnya agama juga dapat menguasai diri seseorang dan membuat ia tertunduk dan patuh kepada Tuhan dengan menjalankan ajaran-ajaran agama. Dengan demikian selanjutnya adalah agama itu membawa hutang yang harus dibayar oleh para penganutnya. Paham kewajiban dan kepatuhan ini selanjutnya membawa timbulnya paham balasan. Orang yang menjalankan kewajiban dan yang patuh kepada perintah agama akan mendapat balasan yang baik dari Tuhan. Namun apabila ada penganut agama yang tidak menjalankan kewajiban dan ingkar terhadap perintah Tuhan akan mendapat balasan yang menyedikan.

Peguatan agama merupakan faktor sebagai penguat ideologi keagamaan. Penguatan agama merupakan hal yang esensisal bagi keberlanjutan identitas ideologi pada seseorang. Selain itu tingkat kematangan ideologi keberaagamaan lebih terukur dibandingan dengan orang orang yang tidak mendalaminya secara intensif. Karena di dalam Islam banyak sekali aliran keagamaan. Terutama di Neagara Indonesia yang memiliki prinsip bhineka tunggal ika yang sangat menghargai perbedaan. Oleh karenanya labih baik kita mendalami perihal penguatan ideologi keberagamaan.

\section{1) Definisi Ideologi Keberagamaan}

\section{a) Definisi Religiusitas (Perilaku Keagamaan)}

Menurut Harun nasution dalam buku Jalaludin, membedakan pengertian agama berdasarkan asal kata, yakni al-din, religi (relegere, religare) dan agama. Al-din berarti 
undang-undang atau hukum. Kemudian dalam bahasa Arab, kata ini mengandung makna menguasai, menundukkan, patuh, dan kebiasaan. Sedangkan dari bahasa religi (latin) atau relegere berarti mengumpulkan atau membaca. Kemudian religare berarti mengikat. Adapun arti kata agama terdiri dari $\mathrm{a}=$ tidak ; gam $=$ pergi, mengandung arti tidak pergi, tetap di tempat atau diwarisi turun temurun.11

Berdasarkan pada istilah agama dan religi tersebut maka munculah istilah religiusitas. Dalam psikologi konsep ini sering disebut sebagai religiusitas. Hal ini perlu dibedakan dari agama, karena konotasi agama biasanya mengacu pada kelembagaan yang bergerak pada aspek-aspek yuridis, aturan dan hukuman sedangkan religiusitas lebih pada aspek lubuk hati' dan personalisasi dari kelembagaan tersebut (Shadily, 1989).

Menurut Jalaludin, perilaku keagamaan adalah suatu tingkah laku manusia dalam hubungannya dengan pengaruh keyakinan terhadap agama yang dianutnya.12

\section{b) Dimensi Keagamaan}

Glock dan Stark,13 adalah salah satu tokoh psikologi, mengatakan bahwa ada lima macam dimensi keberagaman sebagai indikator untuk mengetahui keberagaman seseorang, yaitu:

\section{1) Dimensi keyakinan (Ideologi)}

Keyakinan yang dipakai oleh Djamaludin Ancok adalah akidah Islam, pada dasarnya sudah tertanam sejak manusia ada di alam azali (pra-kelahiran). Akidah akan terpelihara dengan baik apabila perjalanan hidup seseorang diwarnai dengan penanaman tauhid yang memadai.14 Pada dimensi ini memuat pengharapanpengharapan yang mana religiusitas berpegang teguh pada pandangan teologis tertentu dan mengakui

11 Jalaludin, Psikologi Agama, (Jakarta: PT. Raja Grafindo Persada, 2000), hlm. 11

12 Jalaludin, Psikologi Agama, hlm. 11

13 Glock, C. Y. \& Stark, R. Dimensi-dimensi Keberagamaan dalam Robertson, Roland (ed.), Agama: Dalam Analisa dan Interpretasi Sosiologi. (Jakarta:CV Rajawali. 1988), hlm. 19

14 Djamaludin Ancok, Fuat Nashori Suroso, Psikologi Islam., hlm. 
kebenaran-kebenaran. Menurut Maududi, dasar segala bentuk ketaatan dan kepatuhan di dalam Islam ialah iman.15

Dimensi keyakinan dalam penelitian ini adalah tentang keyakinan guru yang di terapkan pada siswa-siswi - siswi SD NU sebagai upaya deridikalisasi dini. Unsur keyakinan dalam diri guru yang menjadi landasan tentang meminimalisir deridikalisasi sejak dini terhadap pengamalannya dalam kehidupan sehari-hari. Karena ciriciri dari ideologi atau keyakinan itu sendiri adalah patuh dan taat terhadap perintah Tuhan, taqwa, menjalankan semua kewajiban yang diperintahkan Tuhan dan mampu menjauhi serta meninggalkan apa-apa yang dilarang oleh Tuhan., serta meyakini sepenuh jiwa apa yang sudah diperintahkan oleh Tuhan adalah yang terbaik untuk kehidupan manusia secara menyeluruh.

\section{2) Dimensi pengetahuan agama (Intelektual)}

Dalam dimensi ini berkaitan dengan pengetahuan tentang ajaran agama yang diyakininya sebagai pedoman oleh setiap individu. Seseorang yang beragama baik pada dasarnya telah mengetahui bermacam-macam ilmu atau memiliki pengetahuan yang dalam terhadap agama yang telah diyakini tersebut. Adapun indikator dari pengetahuan agama pada anak usia sekolah dasar terhadap apa yang telah diyakininya tersebut adalah mengetahui landasan dan hukum Islam secara praktis, mengetahui tujuan beribadah, mengetahui dampak positif dari beriman dan bertaqwa kepada Allah Swt terhadap perilaku keagamaannya, dan mengetahui konsekuensi atas pelanggaran yang dilakukan dalam kesehariannya.

Dalam teori lain pada The Development of Religious on Children, Ernest Harms yang dikutip oleh Bambang Syamsul Arifin mengungkapkan bahwa perkembangan agama yang terjadi pada anak-anak ditentukan oleh tingkat usianya. Perkembangan tersebut merupakan sebuah perkembangan berbagai aspek kejiwaan,

15Husein Shahab, Hijab menurut al-Qur'an dan al-Sunab: Pandangan Muthahhari dan al-Maududi, (Bandung: Mizan, 2013), hlm. 
termasuk perkembangan dalam berpikir.16 Perubahan dan perkembangan yang berlangsung tidak hanya terjadi pada aspek jasmani, ruhani, namun juga dalam kemampuan berpikir, arah minat, alam perasaan, lingkungan pergaulan, sikap, rasa keagamaan, dan sebagainya, yang semuanya adalah perkembangan kepribadian secara menyeluruh meliputi dimensidimensi jasmani, kejiwaaan, keruhanian dan kemasyarakatan.

Dari uraian teori-teori di atas dapat disimpulkan bahwa begitu pentingya seseorang memahami ideologi keberagamaan guna memahami agama secara utuh baik dari aspek tekstual mapuan kontekstual. Oleh karenanya sudah saatnya kita lebih memperhatikan pemahaman ideologi keberagamaan pada anak usia sekolah dasar, karena di jenjang pendidikan itulah pemahaman-pemahaman ideologi keberagaman dibangun dan dibiasakan guna pembentukan karakter secara terencana dan tersistematis. Sehingga pasti akan sangat berdampak pada praktik kebergamaan oleh setiap anak tersebut.

\section{Cultur Sosial Anak Usia Sekolah Dasar}

Dalam dunia pendidikan sudah pasti berkaitan erat dengan multikulturaisme dan pluralisme. Oleh karena itu sangat penting seorang pendidik atau guru mengenalkan kedua hal tersebut kepada anak-anak usia sekolah dasar. Demi mengdepankan misi Negara Indonesia yakni NKRI yang berpedoman pada Pancasila dan semboyan Negara Indonesia yaitu Bhineka Tunggal Ika. Dapat diketahui bahwa multikultural memiliki cita-cita ideal untuk siswa/i, yaitu terwujudnya perdamaian, keadilan, dan persaudaran sosial, anti konflik, kekerasan, dan diskriminatif.17

16 Bambang Syamsul Arifin, Psikologi Agama, (Bandung: Pustaka Setia, 2015), hlm. 80

17 Desy Dorasih, Hambali, Gimin, Pengarub Nilai-Nilai Multikulturalisme Terbadap

Pengamalan Nilai Kerukunan Siswa Kelas X Di SMK Negeri 5 pekanbaru, Program Studi Pendidikan Pancasila dan Kewarganegaraan Fakultas Keguruan Dan Ilmu Pendidikan Universitas Riau 
Untuk lebih mendasar terkait teori-teori multikultural, peneliti merujuk kepada beberapa teori yaitu:

a. Pemahaman nilai-nilai multikultual

Dalam hal ini Desy Dorasih dkk mengutip beberapa teori terkait multikultural diantaranya yaitu:

Menurut Farida Hanum dan Setya Raharja mengatakan bahwa nilai-nilai multikultural sudah termuat dalam visi-misi pendidikan multikultural yang selalu mengutamkaan dan menegakkan serta menghargai pluralisme, demokrasi, dan humanisme, kemudian dengan ketiga hal tersebut para anak didik diharpkan menjadi generasi penerus bangsa yang selalu menjunjung tinggi moralitas, kedisiplinan, kepedulian humanistik, dan kejujuran dalam berprilaku sehari-hari.

Menurut H.A.R. Tilaar Multikulturalisme adalah sebuah paham yang memiliki nilai-nilai yang termaktup didalamnya, yang hendaknya dipelajari dan dipahami oleh masyarakat plural seperti di Indonesia dalam rangka perwujudan persatuan dan kesatuan bangsa.

Adapun ciri-ciri multikultural menurut Tilaar yaitu: 1) Tujuanya membentuk budaya pada manusia dan menciptakan manusia yang berbudaya 2) materi budaya beresensi mengajarkan nilai-nilai luhur pada kemanusian, values bangsa, dan values kelompok cultural. 3) Metodenya demokratis, yang menghargai aspek-aspek perbedaan dan keberagaman budaya bangsa dan kelompok etnis multikulturalis) 4) Evaluasinya ditentukan pada penilaian terhadap tingkah laku anak didik yang meliputi persepsi, apresiasi, dan tindakan terhadap budaya lainnya.

Mustoha mengatakan bahwa teori kerukunan adalah melihat kestaraan pada hubungan sosial yang humanisme dapat terjadi pada setiap interaksi antar elemen masyarakat dan kulturnya dengan setidaknya Lima teori dasar diantaranya yaitu: (a) Teori Nilai ; (b) Teori Struktural ; (c) Teori Idealis ; (d) Teori Resiprositas ; dan (e) Teori Interaksi.

Dalam pandangan Hamzah Tualeka Zn ada Nilainilai kerukunan sebagai wujud solidaritas bangsa diantaranya yaitu: saling menghargai, saling menghormati, saling membantu, saling kerjasama, mengembangkan azas persamaan, kebebasan, dan keadilan, dapat bekerjasama dalam menciptakan keamanan dan kedamaian di tengah- 
tengah kehidupan masyarakat, bangsa dan negara. Dimana nilai-nilai kerukunan ini terdapat dalam ajaran-ajaran agama.

Sedangkan dalam pandangan lain oleh Sosiolog Bergson (dalam Dardji Darmoduharjo) Manusia hidup bersama bukan didasarkan kepada persamaan tetapi oleh karena perbedaan baik dalam sifat, kedudukan, dan lain sebagainya. Kenyataan hidup dapat dirasai karena terdapatnya perbedaan hidup dalam bergolong-golongan. Maka kerukunan antar umat beragama bertujuan untuk :

1. Memelihara eksistensi agama-agama itu sendiri

2. Memelihara eksistensi Pancasila dan UUD 1945

3. Memelihara Persatuan dan rasa Patriotisme

4. Memelihara stabilitas dan ketahanan Nasional

5. Membendung dan mengikis paham sekulerisme dan Atheisme

6. Menunjang dan mensukseskan pembangunan

7. Mewujudkan masyarakat religious18

Teori yang sudah diurakan di atas maka kita harus dapat memahami bersama dan seksama. Dalam hal ini harus diambil hikmahnya pada nilai-nilai kerukunan bahwa setiap perbedaan golongan sebagai pendorong untuk dapat saling mengenal saling memahami dan saling berinteraksi. Ini akan membawa seluruh lapisan masyarakat itu kepada kesatuan dan kesamaan pandangan dalam membangun dunia yang diamanatkan oleh Tuhan YME sebagai Penguasa Jagad Raya.

Dengan demikian, multikulturalisme memang menjadi salah satu amunisi terpenting dalam bersikap sikap saling menghargai kemajemukan yang dapat dicirikan dengan sikap toleransi terhadap perbedaan yang ada, Semboyan Bhinekka Tunggal Ika memiliki makna agar kita dapat menghargai kemajemukan. Pada hakikatnya mengungkapkan perasaan yang terdalam dari kesadaran bangsa Indonesia yang mengenai perlunya kerukunan itu. Kita harus memaklumi dan menerima perbedan-perbedaan baik itu dari segi keyakinan ataupun adat budaya.

18 Desy Dorasih, Hambali, Gimin, Pengarub Nilai-Nilai Multikulturalisme Terbadap

Pengamalan Nilai Kerukunan Siswa Kelas X Di SMK Negeri 5 pekanbaru, Program Studi Pendidikan Pancasila dan Kewarganegaraan Fakultas Keguruan Dan Ilmu Pendidikan Universitas Riau 
b. Karakter prilaku sosial anak

Carakter Educational pada perilaku sosial akhir-akhir ini semakin banyak diperbincangkan, terutama di kalangan akademisi. Hal ini disebabkan sikap dan perilaku masyarakat Indonesia yang cenderung mengabaikan nilai-nilai luhur yang sudah lama dijunjung tinggi dan mengakar dalam sikap dan perilaku sehari hari. Kejujuran, kesantunan, kebersamaan, dan nilai spiritual perlahan mulai terkikis oleh budaya asing yang cenderung hedonistik, materialistik dan individualistik sehingga nilai-nilai karakter perilaku sosial tersebut tidak lagi dianggap penting. Hal ini seirama dengan landasan yuridis yang termaktub dalam UU ataupun PP, dapat diketahui bahwa:19

Kebijakan UU No 20 Tahun 2003 Tentang Sistem Pendidikan Nasional pada Pasal 3 menyebutkan bahwa pendidikan nasional berfungsi mengembangkan kemampuan dan membentuk karakter serta peradaban bangsa yang bermartabat dalam rangka mencerdaskan kehidupan bangsa. Pendidikan nasional bertujuan untuk mengembangkan potensi peserta didik agar menjadi manusia yang beriman dan bertakwa kepada Tuhan Yang Maha Esa, berakhlak mulia, sehat, berilmu, cakap, kreatif, mandiri dan menjadi warga negara yang demokratis serta bertanggung jawab.

Kebijakan tersebut sebagai tindak lanjut dari kebijakan PP Nomor 17 Tahun 2010 tentang Pengelolaan Penyelenggaraan Pendidikan pada Pasal 17 ayat (3) yang menyebutkan bahwa pendidikan dasar bertujuan membangun landasan bagi berkembangnya potensi peserta didik agar menjadi manusia yang (a) beriman dan bertakwa kepada Tuhan Yang Maha Esa; (b) berakhlak mulia dan berkepribadian luhur; (c) berilmu, cakap, kritis, kreatif dan inovatif; (c) sehat, mandiri dan percaya diri; (d) toleran, peka sosial, demokratis dan bertanggung jawab.

Dari beberapa landasan yuridis di atas menunjukkan bahwa betapa pentingnya melaksanakan sebuah pendidikan itu tidak hanya mengajarkan soft skill dan hard skill, namun

19 Taufiqurrahman dan Najminnur Hasanatun Nida, Pendidikan Karakter Perilaku Sosial Anak. Usia Sekolah Dasar Dalam Keluarga Di Kota Banjarmasin, Jurnal Tarbiyah: Jurnal Ilmiah Kependidikan Vol. 8 No. 1 Januari - Juni 2019, hlm. 7590 
lebih dari itu harus bisa mengajarkan sebuah nilai-nilai kehidupan yang sesungguhnya bahwasannya pendidikan karakter dan pengembangan potensi anak itulah yang akan menjadi pagar betis dari kegaduhan beragam konflik dan cemerlangnya masa depan generasi bangsa. Karakter ini tidak akan terbentuk dengan mudah namun bisa dibentuk dan dikembangkan yang harus melalui beberapa tahapan dan tujuan secara jelas serta didukung oleh program-program sekolah yang menunjang. Hal ini menjadi salah satu sorotan penting dalam dunia pendidikan dan wujud dari kualitas pendidikan itu sendiri.

\section{METODE PENELITIAN}

Jenis penelitian ini adalah kualitatif. Menurut sugiono penelitian kualitatif adalah "penelitian yang bersifat holistik dan lebih menekankan proses, sehingga dalam penelitian ini melihat hubungan antar variabel pada obyek yang diteliti lebih bersifat interaktif yaitu saling mempengaruhi (reciprocal/ interaktif)".20 Dalam hal ini peneliti melakukan sebuah observasi terlibat secara langsung terkait penerapan program-program sekolah yang sifatya pengembangan religiusitas dan karakter anak. "Dalam penelitian kualitatif, peneliti adalah sebagai kunci.21

Pengumpulan data memerlukan data primer dan data skunder. Data primer diperoleh dari para guru-guru SD NU Metro Barat. Sedangkan data skunder diperoleh dari siswa, dokumendokumen pendukung dan wali murid.

Analisis data peneliti menggunakan metode analisis kritis, sehingga kajian ini bersifat deskriptif analitis kualitatif guna menjadi sebuah penemuan konsep baru dalam pembelajaran dengan pendekatan Ideologi Beragama Dan Sosial. Penelitian ini menggunakan pendekatan kualitatif dengan dua sistem analisis diantaranya yaitu aspek ideologi dan sosial. Adapun adapun fungsi dari pendekatan ideologi yaitu untuk melihat sistem doktrinisasi keagamaan pada para siswa, sedangkan dari pendekatan sosial fungsinya yaitu untuk melihat perkembangan sosial pada siswa SDNU. Metode yang peneliti gunakan dalam pengumpulan data yaitu: wawancara, observasi dan dokumentasi. Berdasarkan sifat data

20 Sugiono, 2014, Metode Penelitian Kuantitatif, Kualitatif dan ReD, Bandung: Alfabeta, Hlm. 11

21 Sugiono, 2009, Metode Penelitian Kuantitatif, Kualitatif dan R\&D, Bandung: Alfabeta, Hlm. 15 
yang dikumpulkan, maka metode analisis yang data yang digunakan adalah dengan analisa kualitatif.

\section{HASIL dan PEMBAHASAN}

\section{Upaya Pencegahan Radikalisasi Dini Pada Siswa SDNU} Metro Barat Melalui Aspek Ideologi Beragama

Berdasarkan hasil survei dan wawancara di SD NU mempunyai program terkait deradikalisasi dini pada siswa SD NU melalui pendekatan ideologi beragama dengan beberapa program yang sudah rutin dijalankan diantaranya yaitu:

\section{a) Pembiasaan Aspek Religious}

Dalam pembiasaan aspek Religious di SD NU ini merupakan salah satu kegiatan yang selalu dibiasakan diantranya yaitu: 22

a. Sholat dhuha

Hasil intervew di atas dapat dilihat bahwa program sholat dhuha dan peran guru dalam mendampingi sholat dhuha di SD NU mempunyai manfaat tersendiri bahwa guru memberikan pemahaman terkait bagaimana cara siswa untuk memahami terkait kewajiban seorang hamba Tuhan yang beriman dan bertaqwa. Untuk menjadi hanba yang baik tidak hanya pintar secara IQ tapi jg pintar secara SQ.

b. Ngaji sorogan An-Nahdliyah23

Hasil intervew dan observasi di atas dapat diambil kesimpulan bahwa ada nilai tersendiri diantaranya:

1. Para siswa memahami pentingya belajar membaca Al-Qur'an

2. Para siswa memahami manfaat membaca AlQur'an

3. Setiap guru sangat berperan dalam membimbing ngaji sorogan An-Nahdiyah

4. Setiap guru mampu mengarahkan terhadap siswa terkait generasi muslim yang tidak boleh hanya asal membaca dan mengahafal Al-Qur'an. Namun harus memahami ilmu atau cara membaca $\mathrm{Al}$ - 
Qur'an yang baik dengan benar sesuai dengan kaidah ilmu tajwid.

c. Hafalan Juz'ama

Dari hasil wawancara di atas dapat peneliti simpulkan bahwa seluruh siswa mampu mengikuti program Hafalan Juz'ama dengan baik. Hal ini dibuktikan dengan kemampuan hafalan para siswa, buku Hafalan Juz'ama, dan jadwal hafalan yang terjadwal secara rutin. Adapun keterkaitannya dengan deradikalisasi dini adalah para siswa diberi pemahaman terhadap makna-makna yang terkandung dalam surat -suratan pendek tersebut. Sehingga memberikan pemahaman terkait menjadi generasi muslim yang baik dan bukan generasi muslim yang radikal.

d. Pemilihan Materi Dalam Pembelajaran

Dalam hal ini pemilihan materi dalam pembelajaranpun menjadi hal penting dalam upaya pencegan radiklisasi pada usia anak-anak. Dari hasil wawancara di atas dapat peneliti simpulkan bahwa memberi pemahaman tentang ideologi beragama pada siswa usia sekolah dasar bukanlah hal yang mudah. Namun hal ini harus tetap dilakukan karena dari sejak dinilah pencegahan Radikalisme ini dilakukan sebagai pembentukan karakter jiwa muslim yang berkualitas dan religius.

\section{Upaya Pencegahan Radikalisasi Dini Pada Siswa SDNU Metro Barat Melalui Aspek Sosial}

Dalam hal ini d SDNU mempunyai beberapa kegiatan yang merupakan wujud dari adanya pendekaran sosial sebagai upaya pencegahan Radikalisme dini pada siswa. Adapun kegiatan-kegiatan itu diantaranya yaitu:

a. Kegiatan Pramuka

Dari hasil Observasi dan wawancara dapat dilihat bahwa kurikulum 2013 mewajibkan agar seluruh guru dan siswa untuk mengikuti kegiatan pramuka secara aktif. Karena disitu adalah mempunyai muatan pendidikan karakter yang tinggi dan membangun jiwa mandiri yang tangguh. 
b. Kegiatan Bakti sosial

Menurut penjelasan kepala sekolah bahwa pendekatan sosial yang lain adalah bakti sosial yang dilaksanakan setiap hari jum'at berupa infak sodaqoh oleh seluruh siswa. Hasil infak tersebut disalurkan pada LAZIZNU yang nantinya akan menyalurkan infak sodaqoh tersebut kepada yang berhak. Hal ini bertujuan membangun jiwa kepedulian pada para siswa terhadap sesama.24 Informasi tersebut dapat dipahami bahwa di SDNU sudah rutin dalam melaksanakan program bakti sosial bentuk dari pembelajaran dan pengembangan dari kecerdasan emosional pada siswa.

c. Kegiatan kerjasama dalam pembelajaran

Dari penjelasan para guru bahwa disetiap pembelajaran disisipkan proses pembelajaran yang berbentuk kerjasama antara siswa satu dengan siswa lainnya misalnya kegiatan kerja kelompok, hal ini dibiasakan dengan tujuan agar para siswa mampu membangun jiwa solidaritas yang tinggi terhadap teman-temannya.25

Penjelasan guru tersebut dapat dilihat tujuan dan maksud dari medote pembelajaran yang di lakukan oleh para guru bahwasannya guru memberikan pembiasaan bahwa para siswa harus terbiasa dengan kerjasama dalam hal yang baik dan bisa saling menghargai, menghormati, dan membantu kepada siapaun yang membutuhkan itu.

d. Melaksanakan Upacara Bendera

Selain rangkaian kegiatan di atas terlihat pula ada kegiatan rutin di SDNU setiap hari senin yaitu Upacara Bendera, dimana yang diikuti oleh seluruh siswa dan para guru. Dalam kegiatan ini yang ditekankan adalah pengembangan jiwa patriotisme dan nasionalisme pada siswa.26 Dimana setiap siswa digilir untuk menjadi petugas upacara. Mulai dari yang menjadi pembaca susunan upacar sampai kepada pengerek bendera. Hal ini masih dalam bimbingan yang sangat intens oleh para guru, karena siswa yang bertugas adalah siswa kelas 1 dan 2. 
Uraian di atas dapat di lihat adanya singkronisasi judul penelitian yang peneliti lakukan terhadap programprogram sekolah di SD NU Metro Barat. Adapun hasil analisis data dapat di ketahui bahwa pendidikan holistik berbasis karakter bertujuan untuk membentuk manusia yang utuh (whole person) yang cakap dalam menghadapi berbagai tantangan kehidupan, serta memiliki kesadaran spiritual bahwa dirinya merupakan bagian dari keseluruhan (the person within a whole). Beberapa aspek yang harus terpenuhi sebagai manusia yang holistik ialah: Aspek fisik, Aspek emosi, Aspek Sosial dan Budaya, Aspek kreativitas, Aspek spiritual dan Aspek akademik.

\section{Program Unggulan sebagai wujud Deradikalisasi dini} pada sisiwa yaitu: 27

a. Tahfidz Al Quran (juz 30 dan ayat serta surat-surat pilihan)

b. Tahfidz Hadits (hadits-hadits pilihan tentang pendidikan dan amaliyah nahdliyin)

c. Tahsin Al Qur`an metode An nahdliyah

d. Pembelajaran dasar Kitab Kuning

e. Praktek ibadah

f. Hafalan do`a-doa

g. Pendidikan berkarakter

h. Language (Arab \& Inggris)

i. Sains/Olympiade

j. Special event

Dalam program unggulan ini yang berkaitan dengan deradikalisasi adalah point a-g, karena dari ponit - point itu dapat dilihat relevansinya dengan pendekatan ideologi dan sosial dalam upaya deradikalisasi dini untuk siswa SDNU.

4. Ekstrakurikuler (program minat bakat) yang menjadi salah satu bentuk Deradikalisasi dini pada sisiwa yaitu:28

a. Pidato/ceramah agama

b. Tilawatil Qur an

c. Kaligrafi

27 Wawancara dengan kepala sekolah SDNU, pada 5 Februari 2020

28 Wawancara dengan guru-guru SDNU, pada 1 Februari 2020 

d. Hadroh
e. Pramuka

\section{Kompetensi Lulusan Nasional Plus}

Diantara kualitas SDM yang terbentuk antara lain ditandai dengan adanya kebiasaan-kebiasaan yang baik dan terdidik secara moral maupun spiritual. Secara khusus SD NU dalam menerapkan program-program pembiasaan diharapakan setiap peserta didik memiliki keunggulan yang berkebiasaan sebagai berikut:29

a. Selalu ingin tahu dan bertanya (inquirer)

b. Berfikir kritis dan kreatif (critical and creative thinkers)

c. Berpengetahuan luas (knowledgeable)

d. Komunikator yang efektif (efective communicator)

e. Berani mengambil resiko (risk taker)

f. Bersikap terbuka terhadap segala perbedaan yang ada (open-minded)

g. Peduli terhadap orang lain dan lingkungan sekitar (caring)

h. Mempunyai integritas moral (integrity)

i. Mempunyai kesadaran spiritual

j. Tahfidz Al Qur'an juz 30

k. Tahfidz hadits-hadits pilihan

1. Mampu melaksanakan ibadah sehari-hari dengan baik dan benar

m. Mampu melafadzkan berbagai do'a sehari-hari

n. Khatam Alqur'an 30 juz binnadhor dengan menggunakan metode Annahdliyah

\section{PENUTUP}

Data hasil penelitian di atas dengan rincian yang sudah dianalisis membuktikan tentang Mengapa harus ada upaya radikalisasi dini Pada siswa SDNU Metro Barat Tahun Akademik 2019/2020 ( melalui aspek ideologi beragama dan sosial), karena hal ini menunjukkan pentingnya pencegahan radikalisasi dini untuk memperkuat pemahaman ideologi beragama pada anak/siswa sejak dini, sehingga dapat meminimalisir terjadinya doktrinisasi terkait radikalisme

29 Wawancara dengan kepala sekolah SDNU, pada Hari senin 5 Februari 2020 


\section{DAFTAR PUSTAKA}

Arif, Syaiful, Deradikalisme Islam (Paradigma dan Strategi Islam Kultural), Perpustakaan Nasional Republik Indonesia: koekoesan, 2010

Arifin, Bambang Syamsul, Psikologi Agama, Bandung: Pustaka Setia, 2015

Djamaludin Ancok, Fuat Nashori Suroso, Psikologi Islam

Glock, C. Y. \& Stark, R. Dimensi-dimensi Keberagamaan dalam Robertson, Roland (ed.), Agama: Dalam Analisa dan Interpretasi Sosiologi. Jakarta:CV Rajawali. 1988

Jalaludin, Psikologi Agama, Jakarta: PT. Raja Grafindo Persada, 2000

Shahab, Husein, Hijab menurut al-Qur'an dan al-Sunah: Pandangan Muthabhari dan al-Maududi, Bandung: Mizan, 2013,

Syamsuddin, Muh., MUKADDIMAH: Jurnal Studi Islam, Volume 2, No. 1, Juni 2017 , LP2M UIN Sunan Kalijaga Yogyakarta

Thoyyib, M., TA"LIM : Jurnal Studi Pendidikan Islam Vol.1 No.1 Januari 2018

Nata, Abudin, Metodologi Studi Islam, Jakarta: Rajawali Pers, 2010

Yunus, A Faiz, Jurnal Studi Al-Quran, Membangun Tradisi Berfikir Qur'ani doi.org/10.21009/JSQ.013.1.06 Vol. 13 , No. I, Tahun. 2017, Universitas Indonesia 